\title{
SOME MOTIFS IN KOMI LEGENDS ABOUT THE CREATION OF THE WORLD
}

\author{
Pavel Limerov \\ Leading Research Fellow \\ Department of Folklore, Institute of Language, Literature, and History \\ Komi Science Centre, Russian Academy of Sciences, Russia \\ Email: plimeroff@mail.ru
}

\begin{abstract}
The article analyses some scenarios from legends about the creation of the world in the Komi tradition. The text recorded by Pavel Doronin in 1923 contains some storylines that have no parallels in similar texts. First and foremost, it is the story of the creation of the Earth, which is a contamination of mythological motifs of Earth-diving and the creation of the world from an egg. The article considers in detail the main components of the motifs and offers a hypothesis about the origins of these components.
\end{abstract}

Keywords: alkonost, cosmogonic legends, demiurge, proto-Uralic myth, scenario

\section{ORIGINAL COSMOGONIC SCENARIOS}

The myth of creating the Earth is a constituent part of cosmogonic legends. Finno-Ugric mythology knows two world-creation scenarios: 1. a waterfowl grabs the Earth from the bottom of the primary ocean (the myth of a diving bird, hereinafter the MDB), and 2. Earth and other cosmic elements are created out of a bird's egg (the myth of creation out of an egg, hereinafter the MCE).

The latter scenario is most popular among the Western Finno-Ugrians - the Karelians, Finns, Estonians, Saamis, etc., while the MDB was widely spread among the Eastern Finno-Ugrians - the Komi, Udmurts, Mordovians, and Mari (Aikhenvald \& Petrukhin \& Khelimsky 1998 [1980]: 564). Komi folklore knows both variants of the story, although the most popular legend among the researchers and those interested in folklore is the one copied in 1923 by Pavel Doronin, a writer and ethnographer, from a Komi manuscript in the village of Prokopievka (Komi Pron'dor) in what is now the Syktyvdinsky district of the Komi Republic.

The text is a well-developed version of the dualistic world creation legend. It has a clearly defined concept of antagonism between demiurge brothers 
and includes both the creation of all levels of the universe and the creation of a human being. The plot is distinguished by the presence of three, not two, waterfowls, as the beginning of the story features a duck - the mother of the future creators of the world.

The chözh duck was swimming in the primary boundless ocean-sea and carried the eggs of the origin of life. For a long time, she was looking for a place to hatch her ducklings but could not find a safe location. She laid four eggs, but the sea swallowed them and she managed to save only two eggs. Out of these eggs, two children, two ducklings, hatched under the mother duck's wing - En and Omöl'. They were two brothers, two opposite principles - life and death, good and bad, truth and lie, day and night. The mother duck carried them on her back until they came of age and then asked them to bring the lost eggs from the depth of the sea and break the eggs on her body. She flew high up the air, fell against the water, and died. (Doronin 1947)

Then, the legend tells how the ducklings dived to the bottom of the ocean to fetch the drowned eggs, revealing their antagonism: En dived first, and while he was at the bottom, 'Omöl' whistled and shouted so that everything stood still and the ocean surface froze' (Doronin 1947). En got out of the abyss, having broken the ice with lightning. The brothers broke the rescued eggs against the body of their mother duck. Out of the eggs that En broke, the Sun shined, the body of the mother duck grew longer and wider, covered up with grass and forest, and became the Mother Earth, while out of the eggs that Omöl' broke, the Moon shined, and lakes, bogs, and quicksand appeared on the Earth, and demons arose. The brothers got out of the water, stepped on the earth, and turned into human beings. En created useful birds and animals, and Omöl' predators and snakes; then, they created the first people, a man and a woman (Doronin 1947: 105-111, Komi Mythology 1999: 414-415; Limerov 2005: 17-20).

The text was first published by Fiodor Plesovsky, who also offered its first interpretation within the framework of the matriarchate theory, as approved by the Marxist science (Plesovsky 1972: 32-46). Nikolay Konakov has more than once referred to this text. His intention was to read the myths as a preliminary stage 'on the way to reconstruct the paganism of ancient Komi, and further on, the paganism of the Urals' (Konakov 1996: 5). I considered the story told by the legend part of the analysis of the Komi cosmogonic scenarios (Limerov 2002: 4-16). In this article, I will analyse some peculiarities of the scenario and pay attention to specific MCE of the Komi tradition. 


\section{KEYNOTES OF THE COSMOGONIC LEGEND: SINGULARITY OF SEMANTICS}

The analysed legend is a contamination of the MDB and MCE scenarios: a duck hatches eggs, but the world is created by two characters, who dive to the bottom of the ocean to get the eggs. The only thing that these two completely different scenarios have in common is the absence of a support point in the primary ocean that could be the place of origin of the creation. Initially, there is support point in the MDB scenario, where the earth (silt) is taken from the ocean bed, while there is a support in the Western-Finno-Ugric MCE: a bird makes her nest on Väinämöinen's knee (Karelian-Finnish), on a golden bush in the middle of the sea (Estonian), or on a tussock among the primary waters (Izhorian). The egg rolls down into the sea and breaks, and the sky, the earth, and the celestial bodies are formed out of these pieces (Napolskikh 1991: 29).

The following is a re-construction of the MCE Baltic-Finnish pre-form:

A celestial bird flies over the sea, looking for a place to nest, then it finds a tussock, lays three eggs, the wind comes, the eggs fall down in the water, and the Sun, the Moon, the stars (maybe also the earth and the sky) are formed out of the eggs (Napolskikh 1991: 30).

As we can see, the Western-Finno-Ugric version of the text has no bird diving for the egg - the bird lays eggs not on the water, but on the knee of the first man, on a tussock, a golden bush, or any other equivalent of axis mundi (mountain, world tree), and the egg breaks on its own because of the fall, not because the hero of the legend breaks it. That is to say, the MCE scenario requires a very important element as axis mundi for the cosmic egg; therefore, it does not need a waterfowl, who is indispensable for the MDB, and hence, the Estonian and Izhorian myths do not have this pre-Ural archaism.

It is easy to see that both the Baltic-Finnish and Komi MCEs are completely different. The main motif of the latter is diving, with an addition of the motif of a bird laying eggs in the water.

The latter motif (laying eggs in the water) is rather unusual for these kinds of texts and it is rare for a cosmogony. In addition to the Komi-Zyrian, the motif can be also found in a Komi-Permyak legend:

The world was a boundless ocean and a duck was swimming in it. It laid an egg and it fell in the water. A loon dived to the ocean bed, got the egg, and broke it. The top half of the egg became the sky and the bottom halfthe earth. (Konakov 1996: 18)

There is a similar legend in the Mari tradition: 
A duck dived to the bosom of the ocean. She laid two eggs and hatched them under her wings. Two drake brothers, Iumo and Iyn, were born out of the eggs. Then, they dived into the ocean one by one and brought up the earth from the ocean bed in their beaks. The earth brought by Iumo formed a level surface. Iyn choked and spit out earth and saliva. That was how mountains, lakes, and bogs were created on the Earth. (Kaliev 2004: 108)

Both texts are contaminations of the MDB and MCE, although they differ significantly from the Komi-Zyrian scenario. In the latter, the material of the world is the body of the mother duck, but in the Komi-Permyak one, it is the egg (MCE), and in the Mari one, the earth is taken from the ocean bed (MDB). ${ }^{1}$ The absence of support for laying eggs is compensated in the Komi-Permyak text by the fact that the loon breaks the cosmic egg, and in the Komi-Zyrian and Mari texts, the duck hatches the eggs under her wings. ${ }^{2}$ As Konakov (1996: 17) correctly noted, according to the original version of the Komi-Zyrian scenario, the diving bird brought the earth, and the motif of the world creation out of the egg was added later. Evidently, the MDB part of the scenario does not imply the presence of cosmic support in the primary ocean, as the primary waters are empty. Therefore, the contaminated scenario tells about laying eggs on the water. However, this is an ordinary motif neither for the MCE nor for the MDB scenarios, so we may reasonably assume its literary origin.

The parallels of the motifs can be found in the legends of the mythical alkonost (alkyone) bird, going back to Hexameron by John the Exarch and Paleia Tolkovaia (Interpretative Paleia). According to these legends, the alkonost (alkyone) lays eggs in the depths of the sea: 'Alkonost lays her eggs in the depths, and hatches them on the surface of the water' (Belova 2001: 53; Belova \& Petrukhin 2008: 177-179). The influence of the plot of the book on folklore is evident - the duck is related to the alkonost characters (laying eggs in the depths and hatching ducklings in the sea) and the solution of retrieving the drowned eggs is the traditional diving.

\section{LINGUISTIC AND SEMANTIC ANALYSIS OF THEONYMS}

For the Komi-Zyrian scenario, the death of the mother duck is unavoidable, as it is a condition for the actions of the main figures, En and Omöl' (God and Devil). The archetypical model of the dualistic myth, which forms the basis of the text, requires returning to a two-person scenario. Then, the scenario includes a description of the demiurges: 'They were two brothers, two opposite principles - life and death, good and bad, truth and lie, day and night' (Limerov 2005: 18). This description sounds somewhat artificial for an oral text, but it is from the manuscript, so the original text might have been amended by the 
person compiling the handwritten collection. Nevertheless, this description is very important for the particular text, as it expresses the dualism of the demiurges. At the level of composition, it is the main factor that structures the meaning of the rest of the legend.

The opposition between the brothers is revealed in their names as the opposition between 'top' and 'bottom'. The theonym En [enm-] has the meanings of 'god, sky'; Old Perm jen - jenm- means 'god'; Komi-Zyrian, Komi-Permyak, Komi-Yazva jen; Udmurt in - inm- means 'sky', inmar - 'god' - general Perm *jenm- means 'god, sky' // Finnish ilma means 'air, weather', Ilmari[nen] - 'god of air' (mythology) = pre-Perm *ilma- means 'air, sky' (Lytkin \& Gulyaev 1999: 99). The theonym Omöl' in Komi means 'bad, evil, poor, disgusting' (Timushev \& Kolegova 1961: 489), which opposes him to En as a 'bad god' to a 'good god'.

Konakov offered an interesting suggestion that omöl' is linguistically and genetically related to omla, omlöd, omlög 'river bay, backwater, whirlpool, deep place in the river, cavity, pit in the riverbed', and en' omla 'woman's womb' (Konakov 1996: 11; Lytkin \& Gulyaev 1999: 205). Omöl's relation to the water element is confirmed by a version that Omöl' was created from En's spit (Kuznetsova 1998: 63). Karelian and Finnish mythology have semantic and linguistic analogues to these terms. For example, according to Eino Karhu, Ilmarinen is a heavenly demiurge of pre-Finno-Ugric origin < Finnish ilma 'air, air space, sky, weather'. Väinämöinen (demiurge god) < Finnish väinä 'wide river with quiet flow'; Livonian vena 'estuary, channel'; Estonian väin, vein 'estuary, channel' (Karhu 1994: 75-76); compare: Komi omlöd - general Perm *oฑз-l3- 'pit, trench, cavity, recession'; pre-Perm *ă $a$ - 'recession, opening' (Lytkin \& Gulyaev 1999: 205). The comparison of omlöd 'deep place' with en' omla 'womb' can be explained by the similarity of 'a deep water place' and the notion of 'depth' as a symbolic 'bottom' with the female principle. Konakov (1996: 11) makes a well-justified parallel between Komi omla and ancient Turkic umai 'goddess of childbirth' and 'afterbirth, viscera, womb'. These words are close not only phonetically; they are related by the common meaning of fertility and origin, as mythology compares the birth of a child from the mother's womb to the birth of the world from the primary chaos. Nevertheless, as Sergei Averintsev notes, water as chaos refers to the principle of the universal conception and contains both male and female elements: 'As a female element, water is the analogue of the mother's belly and womb... at the same time, water is the fertilising male semen that makes the earth give birth' (Averintsev 1998 [1980]: 240). Therefore, the terms omöl' and omla form the pair of male and female related to the mythological 'bottom'.

It would be appropriate here to recall a hypothesis by Fiodor Plesovsky that the term Omöl' is related to Ioma - a goddess of the matriarchate period, who later transformed into a male god during the patriarchate. He thinks that 
Ioma-Omöl' is a borrowed and inverted name of the western-Finno-Ugric god Jumal, Jumala (Plesovsky 1972: 38).

Konakov also believes that Omöl' is a linguistic analogue of Jumala, Jumalthe theonym of the western Finno-Ugrians. In his opinion, due to the taboo to pronounce the name of the evil god, the Komi used the foreign theonym of the Finnish higher god as a euphemism to refer to their 'dark god' (Konakov 1996: 10-11). The female alter ego of this 'dark' god is revealed in the name of a fairy tale character Ioma and her analogues in the Finnic languages: Komi ioma 'witch' (juma in the Udora dialect of the Komi language) < Finnic, compare Finnish jumala 'god', dialect maajumala 'witch' (Lytkin \& Gulyaev 1999: 100). However, we do not see this as a loan from the Finnic languages, as Komi terms omöl' and ioma have Indo-European linguistic parallels, just like Finnish jumala, jumal.

Setting aside the concept of the primacy of matriarchate, Fiodor Plesovsky's theory about the division of a unique god into male and female counterparts reflects the cosmogonic idea of the division of the primary androgen into the male and female halves. This necessarily implies parallels with the characters of the Indo-European mythologies: Imir is a primary ancestor in the Scandinavian mythology (etymologically, ymir means double, i.e., a bi-gender creature or twin, cf. Irish emnin 'twin', Latvian jumis 'double foetus') (Meletinskiy 1998 [1980]: 510). Ymir, in turn, is genetically related to Indo-Iranian mythological Yama and Yami (Rigveda), Jima and Jimak (Bundahishna) - the couples of the first people, who were the ancestors of the humankind. The names of these characters have the etymological meaning of 'twin' or 'double' (Lelekov 1998 [1980]: 599). Taking into account this correspondence, Ioma would be a twin of Omöl' and, perhaps, this is a theonym of a female god of fertility, similar to the notion of the Mother-goddess (Turk Yumai).

The word omöl' may, through pre-Perm *ăya- 'recession, opening' (Lytkin \& Gulyaev 1999: 205), come from the general Finno-Ugric notion of a woman's womb as a mythical primary principle of origin, chaos. In other words, if the name of the first demiurge $E n$ is related to the notions of 'sky, top, light', i.e. the 'upper world', then the other, demiurge Omöl', would be related to the notions of 'water, darkness, woman's womb', which is semantically equal to the 'bottom' and 'lower world'. Therefore, the term omöl', denoting the 'dark' demiurge, can be the primary theonym to the word omöl' 'bad' and also a primary theonym similar to Kul'.

\section{MOTIF OF THE ANTAGONISM OF DEMIURGES}

The cosmogonic characters are brothers and often they are twins, so the scenario of the legend grants them equal rights in the future universe. Konakov (1996: 12) sees the idea of the original unity of chaos in this primary neutrality of the 
demiurges - as soon as creation begins, the brothers take on opposite roles. Nevertheless, the characters of the diving birds vary in the similar legends of other nations: usually, they are a duck (goose, swan) and a loon, and this variety of the divers' images goes back to the original forms of the text, i.e., the proto-Uralic myth (Napolskikh 1991: 62-63).

In diving for the drowned eggs, the brothers show first signs of rivalry. This incident includes a unique motif of acoustic differentiation of the opponents: while the diving $E n$ is at the bottom of the sea, Omöl' whistles and shouts so that the ocean surface freezes. En responds with thunder and lightning. Whistling and thunder have no parallel in the MDB of any tradition, though its ethnographic analogue can be the Komi belief in the opposition of the two elements: the whistle is associated with evil forces, the wicked dead, the northern wind, while the thunder is associated with God and Prophet Elijah. According to Anatoly Panyukov (2006: 129), 'making chaos sound' is one of the first cosmogonic actions. In other words, this is the first instance of the cosmos existing as an audible structure, and the sounds of the structure have an innate hierarchy - the 'freezing whistle' made by Omöl' is hierarchically lower than $E n$ 's sound of thunder. In other Komi cosmogonic texts, the Omöl' loon makes sounds ('kurlyk-kurlyk'), hoping to scare the En swan, but En answers with thunder and lightning (Limerov 2005: 17). The whistle and the thunder are opposite forces, expressing different degrees of the brothers' creative powers, while Omöl's 'freezing whistle' is literally suppressed by En's thunder and lightning. ${ }^{3}$

That is how the principle of divine suppression of any chaotic manifestations, emanated by the 'dark' co-creator, is ontologically built in the structure of the newly created world. This makes clearer the mechanism of the euphemistic naming of the dark elements on the basis of the semantic pair en (strong, powerful) versus omöl' (poor, bad, weak), as noticed by Konakov (Konakov 1996: 10). ${ }^{4}$

It is worth mentioning that the motif of freezing water is also known in the Komi tradition from a text collected by Alexei Sidorov in 1913: the devil, transformed into a loon by God, dives for the earth, but when going from the bottom up to the surface of the sea, the sea is covered with ice (Limerov 2005: 25). The text does not say explicitly that it was God who froze the water, but it is implied. Perhaps it is a shortened version of the South Slavic cosmogonic legend about stealing a valuable item from Satan:

God sends an angel to collect a valuable item from Satan. The angel tricks Satan into diving to the bottom of the sea, takes the valuable item left onshore, and flies back to the heaven. God covers the sea with ice to stop the pursuit, but Satan breaks through it, chases the angel, almost reaches him, but fails to get back the stolen item. (Kuznetsova 1998: 70)

As for the analysed scenario, however similar the look, the motifs of freezing the water in the Komi and South Slavic texts have different meanings. In the Komi 
legend, the whistle and the ice are immanent to the image of the 'dark demiurge' and illustrate his thrive to win the 'light' brother, while the Slavic motif, according to Aleksandr Veselovskiy (2009: 313), traces its origin to the Bogomil versions of the scenario, where Satan creates the sun crown and God steals it.

\section{OTHER SCENARIOS: PROSPECTS OF STUDYING}

Out of the six eggs laid by the duck, two contain antagonist demiurges and the other four the energies of creation and destruction. That is why the motif of breaking the eggs is so important, as it refers to the release of the energies. Some of the energies set free by the light demiurge transform the quality of the original cosmic material, the body of the duck, and become the earth covered with woods and greens, where the Sun shines in the sky, while the dark demiurge sets free the negative energies, and the Moon appears in the sky, and everything created by the first demiurge shows signs of death: 'lifeless waters flowed on the earth, lakes, bogs, and quicksand opened the abysses' (Limerov 2005: 18).

As soon as the earth was formed, the original unity of the ocean was substituted for the binary combination of water and earth. Then the construction of the dual cosmos begins, originally caused by the antagonism of the mythological characters. Practically all known legends coincide in that the 'dark' demiurge (Satan) spoils whatever his 'light' brother (God) has created and that is why the world is not perfect. As a general rule, the active opposition of the creators is introduced into the scenario by the motif of 'concealing earth': Satan keeps in his mouth some of the earth that he got from the sea bed and spits it on the earth created by the God, which gives rise to mountains, lakes, ravines, etc. on the smooth surface (Kuznetsova 1998: 71). ${ }^{5}$ Komi legends do not have this motif, and the 'spoiling' of the Earth created by En God is explained by the Omöl' Satan being initially 'evil'. In fact, the spoilage of the relief is included in the analysed text only, although it is related to setting the negative energy free from the cosmic egg by the Omöl' Satan. Similarly, the creation of angels and demons is shown as freeing them from the egg, unlike the traditional version of carving them of stone.

The motifs I have analysed represent only the beginning of the original cosmogonic legend. The unique versions of anthropogenesis, cosmic war, and repartition of the world are beyond this article.

\section{NOTES}

1 Vladimir Napolskikh quotes a Latvian version of the MCE as a parallel example of creating the Earth out of the duck's body: God tears apart an eagle and its blood becomes the sea, its body - the mud and the silt. God breaks the egg found inside the 
eagle and the top part of the egg becomes the sky and the bottom part, which fell into the sea and was mixed up with the silt, becomes the earth (Napolskikh 1991: 32).

${ }^{2} \mathrm{~N}$. Konakov interprets this motif as a version of a 'miraculous birth': the way how magic creatures were born in mythological traditions; in the Komi tradition, the godmother gave birth to Jesus from her right armpit (Konakov 1996: 17). Yuri Kaliev also supports this version (2004: 109).

${ }^{3}$ Compare to a Russian legend: 'Following the motion of God's rod, the celestial army appeared, and following the Satanail's whistle, a host of demons' (Kuznetsova 1998: 347).

4 N. Konakov has all the reasons to believe that the term Kul' can be the original name of the dark god, while Omöl' is a euphemism.

5 V. Napolskikh thinks that this motif appeared in the Finno-Ugric and Turk texts under the influence of a popular Christian, maybe Russian tradition (Napolskikh 1991: 138).

\section{REFERENCES}

Aikhenvald \& Petrukhin \& Khelimsky 1998 [1980] = Aikhenval'd, Aleksandr \& Petrukhin, Vladimir \& Khelimskii, Evgenii. Finno-ugorskaia mifologiia. [Finno-Ugric Mythology.] In: Sergei Tokarev (ed.) Mify narodov mira: Entsiklopediia. [Myths of the Peoples of the World: Encyclopaedia.] T. 1. Moscow: Bol'shaia Rossiiskaia entsiklopediia, pp. 563-568.

Averintsev, Sergei 1998 [1980]. Voda. [Water.] In: Sergei Tokarev (ed.) Mify narodov mira: Entsiklopediia. [Myths of the Peoples of the World: Encyclopaedia.] T. 1. Moscow: Bol'shaia Rossiiskaia entsiklopediia, p. 240.

Belova, Olga 2001. Slavianskii bestiarii: Slovar' nazvanii i simvoliki. [Slavic Bestiary: Dictionary of Names and Symbols.] Moscow: Indrik. Available at https://inslav. ru/images/stories/pdf/2001_Belova_Slavianskij_bestiarij.pdf, last accessed on 17 June 2019.

Belova, Olga \& Petrukhin, Vladimir 2008. Fol'klor i knizhnost'. Mifi istoricheskie realii. [Folklore and Book Culture: Myth and Historic Reality.] Moscow: Nauka. Available at https://inslav.ru/publication/belova-o-v-petruhin-v-ya-folklor-i-knizhnost-mifi-istoricheskie-realii-m-2008, last accessed on 17 June 2019.

Doronin, Pavel 1947. Materialy $i$ dokumenty po istorii komi. [Materials and Documents on Komi History.] Nauchnyi arkhiv KomiNTs UrO RAN: F.1, Op. 12, D. 25. L. 105-111.

Kaliev, Yuri 2004. Etnokul'turnyi status mifologicheskogo soznaniia: Genezis, funktsionirovanie $i$ evoliutsiia traditsionnogo mirovospriiatiia (na primere mariiskoi mifologii). [Ethnic and Cultural Status of Mythological Consciousness. Genesis, Functioning, and Evolution of Traditional Perception of the World (Evidence from Mari Mythology).] Diss. (PhD Thesis). Chuvashskii Gosudarstvennyi Universitet.

Karhu 1994 = Karkhu, Eino. Karel'skii $i$ ingermanlandskii fol'klor $v$ istoricheskom osveshchenii. [Karelian and Ingrian Folklore in Historical Perspective.] St. Petersburg: Nauka.

Komi Mythology 1999 = Siikala, Anna-Leena \& Napol'skikh, Vladimir \& Khoppal, Mikhai (eds.) Entsiklopediia ural'skikh mifologii. T. 1. Mifologiia komi. [Encyclopaedia of 
Uralic Mythologies. Vol. 1. Komi Mythology.] Moscow \& Syktyvkar: DIK. Available at https://www.academia.edu/8463469, last accessed on 17 June 2019.

Konakov, Nikolai 1996. Traditsionnoe mirovozzrenie narodov komi: okruzhaiushchii mir. Prostranstvo i vremia. [Traditional Views of Komi Peoples: Environment. Space and Time]. Syktyvkar: Izdatel'stvo Komi NTs UrO RAN.

Kuznetsova, Vera 1998. Dualisticheskie legendy o sotvorenii mira v vostochnoslavianskoi fol'klornoi traditsii. [Dualistic Legends about the Creation of the World in the Eastern-Slavic Folklore Tradition.] Novosibirsk: Izdatel'stvo SO RAN.

Lelekov, Leonid 1998 [1980]. Iima. [Yima.] In: Sergei Tokarev (ed.) Mify narodov mira: Entsiklopediia. [Myths of the Peoples of the World: Encyclopaedia.] T. 1. Moscow: Bol'shaia Rossiiskaia entsiklopediia, p. 599.

Limerov, Pavel 2002. Siuzhety o sotvorenii zemli v komi fol'klornoi traditsii. [Scenarios of the Creation of the Earth in Komi Folklore Tradition.] In: Pavel Limerov (ed.) Fol'kloristika komi. Trudy instituta iazyka, literatury i istorii, Vyp. 63. [Komi Folklore Studies. Proceedings of the Institute of Language, Literature, and History. Vol. 63.] Syktyvkar: Izdatel'stvo Komi NTs UrO RAN, pp. 4-16.

Limerov, Pavel (comp.) 2005. Mu puks'öm - Sotvorenie mira. Mifologiia naroda komi. [Creation of the World. Komi Mythology.] Syktyvkar: Komi knizhnoe izdatel'stvo.

Lytkin \& Gulyaev 1999 = Lytkin, Vasilii \& Guliaev, Evgenii. Kratkii etimologicheskii slovar' komi iazyka. [The Concise Etymological Dictionary of the Komi Language.] Syktyvkar: Komi knizhnoe izdatel'stvo.

Meletinskiy 1998 [1980] = Meletinskii, Eleazar. Imir. [Ymir.] In: Sergei Tokarev (ed.) Mify narodov mira: Entsiklopediia. [Myths of the Peoples of the World: Encyclopaedia.] T. 1. Moscow: Bol'shaia Rossiiskaia entsiklopediia, p. 510.

Napolskikh, Vladimir 1991. Drevneishie etapy proiskhozhdeniia ural'skoi iazykovoi sem'i: Dannye mifologicheskoi rekonstruktsii (praural'skii kosmogonicheskii mif). [Ancient Stages of Origin of the Uralic Language Family: Mythological Reconstruction Data (Proto-Uralic Cosmogonic Myth).] Narody Ural'skoi iazykovoi sem'i. [Peoples of the Uralic Language Family.] Vyp. 5. Moscow: Institut etnologii i antropologii AN SSSR. Available at https://www.academia.edu/14755985, last accessed on 17 June 2019.

Panyukov 2006 = Paniukov, Anatolii. Marginalii komi muzykal'noi kul'tury: Mir ptits. [Margins of Komi Musical Culture: World of Birds.] In: T. Kaneva (ed.) Narodnaia kul'tura Evropeiskogo Severa Rossii: Regional'nye aspekty izucheniia. [Folk Culture of European North of Russia: Regional Aspects of Studies.] Syktyvkar: Izd-vo SyktGU, pp. 126-150.

Plesovsky 1972 = Plesovskii, Fedor. Kosmogonicheskie mify komi i udmurtov. [Cosmogonic Myths of the Komi and Udmurts.] In: Iakov Beznosikov \& Anatolii Mikushev (eds.) Etnografiia $i$ fol'klor komi. [Komi Ethnography and Folklore.] Vyp. 13. Syktyvkar: Izdatel'stvo Komi filiala AN SSSR, pp. 32-46.

Timushev, Dmitriy \& Kolegova, Nina (comps.) 1961. Komi-russkii slovar'. [Komi-Russian Dictionary.] Moscow: Gosudarstvennoe izdatel'stvo inostrannykh i natsional'nykh slovarei.

Veselovskiy 2009 = Veselovskii, Aleksandr. Dualisticheskie pover'ia o mirozdanii. [Dualistic Beliefs of the Universe.] In: Sergei Levit (ed.) Izbrannoe: Traditsionnaia dukhovnaia kul'tura. [Selected Works: Traditional Spiritual Culture.] Moscow: Rossiiskaia politicheskaia entsiklopediia, pp. 263-361. 